\title{
Media Literacy and the Emerging Media Citizen in the Nordic Media Welfare State
}

\author{
Michael Forsman
}

Södertörn University, Sweden

\begin{abstract}
Since the 1960s, there has been a thriving Nordic tradition of media literacy research, pedagogics, and policy on how to best prepare the emerging media citizen for an increasingly mediatised society. Although the Nordic model of media literacy has previously been characterised by connections to Bildung, critical theory, cultural studies, and progressive pedagogics, much of today's understanding of media literacy is associated with a more instrumental understanding of education, with connections to the commercialisation and digitalisation of compulsory education. By suggesting a historisation of the Nordic media literacy tradition, in connection to the Nordic media welfare state, this article opens a debate about the future directions of Nordic media literacy.
\end{abstract}

Keywords: mediatisation, media literacy, media citizen, media welfare state, historisation

\section{Introduction}

When looking at the media ecology of the 2020s, a question arises: How can we best protect and empower the emerging media citizen in times of deep mediatisation for a globalised and digitalised world (c.f. Couldry \& Hepp, 2017; Mihailidis, 2014) ${ }^{1}$ Since the 1960 s, one of the main answers to this question has been media literacy - or, in other words, the training of children and youth to be participatory and democratic, responsible and critical, creative and expressive, and constructive and reflective media users. The main route to this ideal has been compulsory education and a combination of media as knowledge object (technology, history, theory, etc.) and pedagogical form (production, analysis, and critique). Hence, media literacy can be regarded as the outcome of media education within the system of compulsory education (Buckingham, 2003). Media literacy should also be understood as a mix of pedagogics, policy, and research (Erstad, 2010).

From a historical standpoint, media literacy research and media pedagogics have been related to the traditions of Bildung, critical theory, and progressive 
pedagogics (Buckingham, 2019; Livingstone et al., 2008), not least in the Nordic region (Erstad, 2010). However, a more policy-oriented, administrative, and applied understanding of the field is now occurring. One consequence of this is that the driver of change in this field has shifted from academics and teachers to policymakers and new media industries (Carlsson, 2019a). In this context, media literacy tends to become an individualised form of preparation of future media consumers, which could be interpreted as a substitute for media regulation (Drotner et al., 2017). One part of this tendency is the implementation of concepts such as digital competence, which is connected to the general digitalisation of public education, and thus also to how media education is handled (Godhe, 2019). The concept of media and information literacy is also a part of this.

In this article, I take a historical approach to these matters in order to discuss the Nordic tradition of media literacy. I do this with a focus on research, while referencing pedagogics and policy. My historisation of media literacy can be considered in line with similar international tendencies (e.g., Carlsson, 2019a; Hobbs, 2016), and it should be noted that the Nordic media literacy tradition has been mentioned before (e.g., Carlsson, 2014; Erstad, 2010; Staksrud, 2014; Wadbring \& Pekkala, 2017). Furthermore, it has been manifested (at least indirectly) in contributions to and compilations made by Nordic media researchers studying children, youth, media, and education in publications from Nordicom, and in compilations made in collaboration with UNESCO's International Clearinghouse on Children, Youth, and the Media (e.g., Carlsson, 2010a; Kotilainen \& Arnolds-Granlund, 2010). My preliminary history of - and meta-commentary on - the Nordic media literacy tradition is based on these sources, although a fuller history still needs to be written. My aim here is rather to (re)open a discussion among media researchers about possible future directions of Nordic media literacy and the contributions that media studies can offer.

I argue for a need to reconnect with the history of Nordic media literacy research and suggest a connection between media literacy and the media welfare state, which is the concept that Syvertsen and colleagues (2014) use to describe similarities between Nordic countries in terms of media systems and media history. In addition, I propose that the ideal of media literacy and the practices of media education are - and certainly have been - an element in the construction of the media welfare state, and therefore have also played a part in the creation of national identities and the larger citizen-making enterprise of public education (c.f. Wan, 2014).

In the first section of this article, I present some main assumptions within the media literacy tradition in general. I then provide an outline of some of the characteristics of the Nordic media literacy tradition. In conclusion, I address some challenges currently being confronted in Nordic media literacy research and suggest some possible routes forward. 


\section{Media literacy matters}

There are numerous definitions of media literacy (Potter, 2010), but probably the most cited definition is, the ability to access, understand and create communications in a variety of contexts (Aufderheide, 1993). Media literacy is often linked to free and democratic media (c.f. Carlsson, 2019b), and to critical thinking and critical consciousness (Forsman, 2019; Kellner \& Share, 2019). As a field of pedagogics, research, and policy (Erstad, 2010), media literacy is an area in which cultural politics, media politics, and media regulation intersect. Many different stakeholders hold an interest in the field of media literacy, including authorities, the media industry, NGOs, researchers, parents, children, and more (Carlsson, 2019c). There have also been strong beliefs in media education as an antidote - or even as a "magic bullet" - to what have been experienced as the dangers of media in relation to younger generations (Buckingham, 2003).

According to Potter (2010), media literacy is based on the assumption that the media are central to the socialisation of children and youth, and that certain forms of media content or media technologies (often "new media") can have negative impacts. Behind this discussion about the opportunities of media and how to best protect and empower the emerging media citizen there are two main paradigms. The first paradigm has a cognitivist and functionalistic orientation - along with a focus on media messages and media effects - and is often treated in a segmented and individualistic manner (c.f. Potter, 2010). The second paradigm is oriented toward a more holistic understanding of media, and focuses on media use, sociocultural contexts, identity, media power, and so forth (Kellner \& Share, 2019).

Media literacy and media education are elements within the larger "citizenmaking enterprise" of compulsory education (Wan, 2014). More specific media literacy involves the qualification, socialisation, and subjectification of the emerging media citizen, who is intended to be a democratically participating, critically thinking, and culturally expressive social subject destined for a deeply mediatised society (Forsman, 2018, 2019). This creation and regulation of an ideal subjectivity is based on a reformist and democratic discourse with self-government as its main principle. This "technology of citizenship" (Cruikshank, 1999) can be related to the media welfare state, and thus to the specific character of media systems and media histories in the Nordic countries. For example, the media welfare state is characterised by a pluralistic and corporativist media market, democracy, freedom of speech, and public service; it is also associated with the general welfare system (like public schools). It is not only based on regulatory principles (e.g., press subsidies and public service monopoly), but also on policy solutions and principles that are meant to govern media and communication in a durable and consistent way. My suggestion is that the media literacy discourse and practices as part of compulsory education can be regarded as a dimension of the latter.

According to Syvertsen and colleagues (2014), the media welfare state rests on four pillars. The most important of these pillars in relation to media literacy 
is the "preference for consensual policy making and compromises between different stakeholders" (Syvertsen et al., 2014: 2). ${ }^{2}$ As I discussed later on, this is a preference that has been manifested in, for example, collaborations between public education and external interest from the media industry, governmental authorities, NGOs, or others who have offered teaching material, in-service training for teachers, and more.

Before discussing the history of Nordic media literacy research, something should be said about the connection between media literacy and progressive pedagogics. Progressive pedagogics (pioneered by thinkers such as John Dewey) is a modern ideal of teaching and learning. Among its epistemological principles is a strong focus on experience (i.e., learning by doing, dialogue teaching, and explorative and inquiry-based methods). Another trademark is the use of teaching materials and methods that are related to contemporary society and relevant to students' everyday life. This view has opened up the classroom to modern communication and educational technologies such as instructional films and school television (Cuban, 1986). Another - and in the present case, more important connection is the relation between changes in the technologies, institutions, and logics of media society (i.e., mediatisation) and the ongoing development of media education as a way to respond to these changes.

\section{Some historical posts}

Schools have always been media spaces, and all teaching and learning is media dependent (from blackboards to tablets). In the US, modern media such as film and radio were included as educational technologies as early as the 1920s (Cuban, 1986). In the UK, discussions on media and education focused more on worries of cultural decline due to the expansion of mass media; in the 1930s, many teachers (often those teaching English) became engaged in how to cultivate the moral and aesthetic judgement of their students (especially those from the working class). These teachers wanted to help their students to "scrutinise" media and differentiate between "good" and "bad" - especially in the field of reading. One of the main methods used in this type of cultivation was neglect; in other words, no popular media was permitted in the classroom (Masterman, 1985). This method changed in the early 1960s with "the popular arts movement", and the ambition to incorporate mass media in the classroom became prevalent. However, this was not an example of affirmative action; it was another way to train students to discriminate, albeit now between various categories of popular culture (Hall \& Whannel, 1964).

\section{From film to video}

Film was the medium that first evoked the media pedagogical impulse in the teacher community. As early as the 1950s, teachers in the UK and France started to teach about fictional film (often with inspiration from the French New Wave). 
Film was now studied as an art form, a language, and a technology. Some teachers even allowed their students to make their own short films (Masterman, 1985). A similar development can be found in the Nordic region, where, for example, Danish teachers began to work with filmkundskab [film knowledge] in the 1950s (Tufte, 1995). Liberal arts-oriented work around film knowledge was also initiated in Finland around the same time; Kupianinen and colleagues (2008) even suggest that it played a part in the post-World War II constitution of Finnish national identity and its new citizenship ideal. In Sweden, film knowledge was included in the national curriculum in 1962; however, it was not until the 1980s that film pedagogics became the backbone of Nordic media literacy work. At that point, the national film institutes began producing teaching materials for teachers to use when screening film or video in class, or before taking their students to "a real movie theatre" (Stigbrand, 1989).

Another example of a long-term collaboration between state (education) and market (media industry) in the Nordic region has been the long-lived and widereaching initiative "Newspapers in school”. The format was Anglo-American in origin and was established in Finland and Sweden in 1964 (and somewhat later in Norway and Denmark). One goal of this initiative was to stimulate students' reading ability by using newspapers as a complement to schoolbooks. The newspaper was treated as a study object in itself (i.e., "what is news?") and as a media pedagogical form (i.e., "make your own school paper" or "visit the editorial board at your local paper"). It is reasonable to suspect a hidden agenda behind this - the press industry may have offered free newspapers for school classes and newspaper consultants in the classroom to help cultivate future readers and consumers.

Public service has also been an important collaborator for media education in public schools, first through school radio and school television, and then as a partner in media literacy ventures. These and other collaborations between the educational system and stakeholders on the media market have been essential to the Nordic media literacy tradition, and could - using the terminology from Syvertsen and colleagues (2014) - be described as part of the preference for consensual policy making and compromises between different stakeholders within the media welfare state.

In the 1970s, a great deal of media pedagogics and academic commentary around media education found inspiration in a Marxian understanding of mass culture, not seldom in combination with semiotics inspired by Roland Barthes and the liberational pedagogics of the Brazilian pedagogue Paulo Freire. Len Masterman (1985) was one of the key thinkers in this; he inspired many Nordic teachers with his pedagogical methods for analysing popular television in the classroom. Masterman's deconstruction of commercial messages and media mythologies was based on a non-hierarchical pedagogical dialogic model involving the shared experience of teachers and students analysing popular media texts together in the classroom. The aim was to cultivate a critical consciousness of media power. 
The method was close readings, and the stop-motion button on the VCR and the remote control were the means.

Video technology changed media education in other respects as well. By using video cameras in class, students could make their own films in which they could express their identity and opinions (Drotner, 1991). VCRs gave young people the opportunity to watch film in a more secluded way with their peers, often beyond the control of the adult world. This media reception soon became associated with "video violence" and even led to a "moral panic" in Sweden, which became a starting point for more systematic academic and political work around young people's media use and for the propagation of media education as the best way to protect and empower the emerging media citizen (von Feilitzen \& Carlsson, 1998). In Sweden, a government council for monitoring media violence was established in 1991. This was the embryo of the Swedish Media Council, the governmental agency that today aims to protect minors from harmful media influences by empowering them as critical media consumers.

With new forms of agency evolving around the use of video and satellite television, changes in media literacy research emerged, as a shift in interest occurred from media effects and media ideology (i.e., regulation and protection) to a more affirmative and explorative approach (i.e., empowerment through production). This phenomenological and culturalist shift toward media reception and an interest in how young people use media to create meaning, social community, and self-expression led to an ethnographic turn in research methods in Nordic research on children, youth, and media literacy (c.f. von Feilitzen, 2004; Rydin, 2003).

\section{New terms for a reformed field}

Although there was a wide awareness among media researchers, teachers, and others of the importance of media education as part of civic education, it was not until the 1990s that the term media literacy came into Nordic media education (e.g., Erstad, 1998). Before this, terms such as media pedagogics and media knowledge [Mediekunnskap] were used (Stigbrand, 1989; Tufte 1995). In Finland, mass media education became a keyword in the 1970s (Jaakkola, 2018a). This term was suggested by media researcher Sirkka Minkkinen (1978) in her universal model for media education, which she created on a commission from UNESCO. Minkkinen suggested a media education curriculum that would be based on scientific data from mass communication research or other fields, and that would include all forms of mass media, which would then be related to children's cognitive, cultural, psychological, and social development. The aim of this ambitious and broad curriculum was not only to inform students about mass media, but to also train them in how to use mass media in a responsible way and how to understand the role of media in a democratic system (Minkkinen, 1978).

In Denmark, the term media Bildung suggested a more holistic approach, as the term was connected to sociocultural approaches to learning. This can be 
noticed in, for example, Birgitte Tufte's (1995) study of how media is used for informal learning in the parallel learning system of leisure, peers, and media outside of formal education. Similar propositions can be found in Kirsten Drotner's (1991) study of identity work and how young people engage in making videos as part of a media pedagogical ambition. In Norway, the concept of media knowledge represented a wide area of communication theory, visual analysis, film knowledge, mass media analysis, and computer technology (Dahl, 1984). Eventually, however, in the 1990s, Ola Erstad (1997) changed this discourse by suggesting concepts such as digital literacy and digital competence to connect media literacy to computers, the Internet, and cell phones (Erstad, 2005).

\section{The Finnish paragon}

In overviews and discussions of the Nordic media literacy tradition, Finland is often mentioned as "the good example" (c.f. Dunås, 2014). This is an accurate view, since Finland incorporated mass media education in its curriculum in the 1970s (Kupiainen et al. 2008; Minkkinen, 1978). A more recent development in media literacy occurred when the Finnish government established a programme for more active democratic citizenship in 2003. A national mapping of stakeholders in the field was then done in 2005. This led to an encouragement of cross-disciplinary research and to increased international engagement. Another emphasised area was media education as part of national teacher education (in Finland today, there are two master's programmes focusing on media literacy and digital competence).

A way to connect governmental agencies and NGOs such as the Finnish Society on Media Education (Mediakasvatusseura/Sällskapet för mediefostran, founded in 2005) to more systematic models for media literacy training has been suggested (Jaakkola, 2018a). One effect of this effort has been the establishment of The Finnish Centre for Media Education and Audiovisual Media (MEKU), which has been part of the National Audiovisual Institute (KAVI) since 2012, and has been responsible for the coordination and promotion of safe media environments and media education, and the development of children's media skills. In Good Media Literacy; National Policy Guidelines 2013-2016, the Finnish government stated that media education was a form of social inclusion (Valtioneuvosto Statsrådet, 2013). The Media Policy Programme 2019-2023 underlines the importance of campaigns against disinformation and hate speech, and the importance of adequate media education as a mandatory part of teachers' education (Harrie, 2018a; cf. Jaakkola, 2018b, 2019).

\section{The Nordic media literacy tradition under reconsideration}

Of course, a miniature history such as the one presented here cannot do justice to the variations and complexities of the rich Nordic tradition of media literacy research, pedagogics, and policy. However, some characteristics are worthy of 
mentioning. First, several researchers have suggested that there are strong historical connections between Nordic media literacy, the public school system, the media welfare state, and the general welfare state (Carlsson, 2010b; Erstad, 2010; Staksrud, 2014). Staksrud mentions principles for democratic education and respect for the rights of the child as being central to how media education is understood in Nordic countries. She also suggests that the Nordic debate on media education has shifted from protection by regulation to empowerment by advice and information. Furthermore, she describes the Nordic media literacy model for policy and education as a well-balanced mix of children's right to personal freedom in relation to the affordances given by new media, and the need for protection and guidance from the adult world (Staksrud, 2014). Staksrud also notes that children in the Nordic region often have parents, siblings, teachers, or others safeguarding and challenging their media habits.

Nordicom and their collaboration with UNESCO's International Clearinghouse on Children, Youth, and the Media are other important aspects of Nordic media literacy research. This collaboration has largely been conducted by Ulla Carlsson, and has resulted in a number of publications (e.g., Carlsson, 2010a; Kotilainen \& Arnolds-Granlund, 2010). Carlsson took the initiative to implement the concept of media and information literacy in the Nordic countries (Carlsson, 2014; c.f. Wadbring \& Pekkala, 2017). Media and information literacy was originally suggested by UNESCO in 2011 in connection with human rights (e.g., freedom of speech) and children's rights (to information, personal expression, participation, etc.). Today, media and information literacy is mainly used along with criticism of sources and fact checking as ways to counter disinformation and fake news (Harrie, 2018b).

Digital competence is another concept that seems to be defining how media is currently thought about and taught in Nordic countries (Godhe, 2019). Digital competence is one of the eight so-called twenty-first-century skills that the European Union and OECD have proclaimed necessary for future work, citizenship, and personal development, and it is often connected to employability and lifelong learning.

Here, it should be noted that both media and information literacy and digital competence are somewhat loose concepts, meaning that they lack a generally accepted definition. This makes them useful in the circuits of policy making and governance, where different agents can use them for various descriptive, regulative, and connective purposes. This logic is related to an ongoing shift in the ideals for training the emerging media citizen, from explorative pedagogics and research to transnational policy making (c.f. Carlsson, 2019b). One risk with this is that media education becomes equalised with a set of instrumental and individualised skills, disconnected from Bildung and critical theory and instead linked to the products and interests of the expanding industry of educational technologies (ed-tech). This means that the ideals of the progressive, explorative, and collaborative pedagogics that have long guided the Nordic media literacy tradition are becoming substituted with what educational philosopher Gert Biesta (2010) calls 
learnification, which refers to the tendency to only consider knowledge that is measurable and predictable as legitimate. In response to this risk, I suggest that we do not forget the contextual understanding of young people's media use that has been developed within Nordic media literacy research - for example, in Drotner's and Erstad's work around the blurred boundaries between formal and informal learning, and their use of concepts like identity work (Drotner, 1991, 2007) and learning lives (Erstad et al., 2016; c.f. Drotner \& Erstad, 2014).

\section{Conclusions and routes forward}

In this article, I have made some preliminary remarks regarding the tradition of Nordic media literacy research in connection to policy and pedagogics, and suggested certain links between Nordic media literacy research and the traditions of Bildung, progressive pedagogics, and sociocultural perspectives on learning. Furthermore, I have suggested that media literacy in the Nordic region can be considered as part of the construction of the Nordic media welfare state. However, both the Nordic media welfare state and the general welfare system are challenged by globalisation, marketisation, and neoliberal governance - in combination with new demographics, growing economic inequalities, and wider social gaps. The Nordic media welfare system must revise itself in accordance with the new media ecology of platform media, social media, and so forth.

There is also a noticeable tendency in the media literacy field to shift away from previous processes of bottom-up engagement with researchers and teachers as the driving force behind media literacy. Today, media literacy seems to be more of a top-down process in which policy makers and authorities propose their "curriculums", which are defined by loose concepts and filled with frameworks, indicators, modules, and so forth that challenge, at least in part, some of the core ideals of Bildung and (continental) critical thinking. So, what is there to do, discuss, and safeguard in terms of the core values of the Nordic media literacy tradition?

In terms of policy, Ulla Carlsson (2019c) has underlined a continued need for good governance, which includes sustainable infrastructures for collaborations between authorities, NGOs, and private interests. This idea of consensual orientation has long been central to the construction of the Nordic media welfare state and to the media literacy field. However, it is now challenged by platform companies and others with a strong influence on public education (Forsman, 2018, 2019). Here, it is necessary to ask critical questions about underlying commercial interests and their relation to media education, and how the idea of consensual orientation has been used to legitimate deregulation (c.f. Drotner, et al., 2017).

In terms of pedagogics, there is a need for a renewal of media literacy methods. An increased use of digital opportunities and more analytical work on the infrastructures of media inside and outside the classroom is needed here. In this area, the Nordic media literacy tradition can offer a holistic and explorative understanding of media and of critical and inquiry-based methods for media analysis. 
However, in order to uphold the legitimacy of the field, we also need more evidence-based research that can tell us if, when, and under what circumstances media education and media literacy interventions actually work, both from a shortand long-term perspective. We also need data that can help us compare nations and different groups in terms of media literacy capacities, and it is important not to fall for new dreams of media literacy as a "magic bullet" in these complex times of participatory media, algorithmic power, and platform capitalism. Instead, we should further develop and acknowledge the richness of the Nordic media literacy tradition.

\section{Notes}

1. This article originates from the research project, "Media Citizenship and the Mediatization of School: Curricula, Educational Materials, Teachers” (Forsman, Ericson; Riksbankens Jubileumsfond. For the advancement of humanities and social science, 2015-2019).

2. The other pillars are the organisation of vital communication services as a generally accessible public utility and good; a framework for editorial freedom and self-governance for the media sector; and cultural policies that secure diversity and quality.

\section{References}

Aufderheide, P. (1993). Media literacy: A report of the national leadership conference on media literacy. Aspen, Colorado: Aspen Institute. https://files.eric.ed.gov/fulltext/ED365294.pdf

Biesta, G. (2010). Good education in an age of measurement: Ethics, politics, democracy. London: Routledge. https://doi.org/10.4324/9781315634319

Buckingham, D. (2003). Media education: Literacy, learning and contemporary culture. Cambridge: Polity Press.

Buckingham, D. (2019). The media education manifesto. Cambridge: Polity Press.

Carlsson, U. (Ed.). (2010a). Children and youth in the digital media culture: From a Nordic horizon. Gothenburg: Nordicom, University of Gothenburg/The International Clearinghouse on Children, Youth and Media.

Carlsson, U. (2010b). Young people in the digital media culture: Global and Nordic perspectives an introduction. In U. Carlsson (Ed.), Children and youth in the digital media culture: From a Nordic horizon (pp. 9-24). Gothenburg: Nordicom, University of Gothenburg/The International Clearinghouse on Children, Youth and Media.

Carlsson, U. (Ed.) (2014). Medie- och informationskunnighet $i$ Norden: en nyckel till demokrati och yttrandefribet: rapport frän nordiskt expertmöte i Stockholm den 2 oktober 2013 [Media and information literacy in the Nordic countries: A key to democracy and freedom of expression. Report from a Nordic expert meeting in Stockholm 2 October 2013]. Gothenburg: Nordicom, University of Gothenburg.

Carlsson, U. (2019a). Media and information literacy: Field of knowledge, concepts and history. In U. Carlsson (Ed.), Understanding media and information literacy (MIL) in the digital age: $A$ question of democracy (pp. 37-56). Gothenburg: Nordicom, University of Gothenburg.

Carlsson, U. (2019b). MIL in the cause of social justice and democratic rule. In U. Carlsson (Ed.), Understanding media and information literacy (MIL) in the digital age: A question of democracy (pp. 11-24). Gothenburg: Nordicom, University of Gothenburg.

Carlsson, U. (2019c). How to organize media and information literacy (MIL) on the national level? In U. Carlsson (Ed.), Understanding media and information literacy (MIL) in the digital age: $A$ question of democracy (pp. 67-74). Gothenburg: Nordicom, University of Gothenburg.

Couldry, N., \& Hepp, A. (2017). The mediated construction of reality. Cambridge: Polity Press.

Cruikshank, B. (1999). The will to empower: Democratic citizens and other subjects. Ithaca, New York: Cornell University Press.

Cuban, L. (1986). Teachers and machines: The classroom use of technology since 1920. New York: Teachers College Press.

Dahl, A-G. (1984). Mediekunnskap: Om dannelsen av et nytt fagområde i skolen [Media knowledge: About the creation of a new school subject]. Oslo: Aschehoug.

Drotner, K. (1991). At skabe sig-selv: Ungdom, aestetik, padagogik [To create oneself: Youth, aesthetics, pedagogics]. Copenhagen: Gyldendal. 
Drotner, K. (2007). Leisure is hard work: Digital practices and future competencies. In D. Buckingham (Ed.), Youth, identity, and digital media (pp. 167-184). Cambridge, Massachusetts: MIT Press.

Drotner, K., \& Erstad, O. (2014). Inclusive media literacies: Interlacing media studies and education studies. International Journal of Learning and Media, 4(2), 19-34. https://core.ac.uk/ download/pdf/50696491.pdf

Drotner, K., Frau-Meigs, D., Kotilainen, S., \& Usitalo, N. (2017). The double bind of media and information literacy: A critical view on public policy discourses about MIL. In D. Frau-Meigs, I. Velez, \& J. F. Michel (Eds.), Public policies in media and information literacy in Europe: Cross-country comparisons (pp. 269-283). New York: Routledge. https://doi.org/10.4324/9781315628851

Dunås, J. (2014). Medie- och informationskunnighet i de nordiska länderna: En översikt [Media and information literacy in the Nordic countries: An overview]. In U. Carlsson (Ed.), Medie- och informationskunnighet $i$ Norden: En nyckel till demokrati och yttrandefribet [Media and information literacy in the Nordic countries: A key to democracy and freedom of speech] (pp.17-62). Gothenburg: Nordicom, University of Gothenburg.

Erstad, O. (1997). Mediebruk og medieundervisning [Media use and media education] [Dissertation, University of Oslo, Norway].

Erstad, O. (1998). Media literacy among young people: Integrating culture, communication and cognition. In B. Höijer, \& A. Werner (Eds.), Cultural cognition: New perspectives in audience theory (pp. 85-101). Gothenburg: Nordicom, University of Gothenburg.

Erstad, O. (2005). Digital kompetense i skolen: En innforing [Digital competence in schools: An implementation]. Oslo: Scandinavian University Press.

Erstad, O. (2010). Media literacy and education: The past, present and future. In S. Kotilainen, \& S-V. Arnolds-Granlund (Eds.), Media literacy education Nordic perspectives (pp. 15-28). Gothenburg: Nordicom, University of Gothenburg.

Erstad, O., Kumpulainen, K., Mäkitalo, Å., Schrøder, K. C., Pruulmann-Vengerfeldt, P., \& Jóhannsdóttir, T. (Eds.). (2016). Learning across contexts in the knowledge society. Rotterdam: Sense Publishers. http://dx.doi.org/10.1007/978-94-6300-414-5

Forsman, M. (2018). Digital competence and the future media citizen: A preliminary conceptual analysis. The Journal of Media Literacy, 1-2, 24-29.

Forsman, M. (2019). Rebalancing MIL: The revised Swedish curriculum and the emerging media citizen in a new media ecology. In U. Carlsson (Ed.), Understanding media and information literacy (MIL) in the digital age: A question of democracy (pp. 149-156). Gothenburg: Nordicom, University of Gothenburg.

Godhe, A-L. (2019). Digital literacies or digital competence: Conceptualizations in Nordic curricula. Media and Communication, 7(2), 25-35. http://dx.doi.org/10.17645/mac.v7i2.1888

Hall, S., \& Whannel, P. (1964). The popular arts. London: Hutchinson.

Harrie, E. (2018a, September 13). New media policy guidelines in Finland. Retrieved April 7, 2020, from https://www.nordicom.gu.se/en/latest/news/new-media-policy-guidelines-finland.

Harrie, E. (2018b, September 27). Three Nordic countries to increase MIL among all citizens. Retrieved April 7, 2020, from https:/www.nordicom.gu.se/en/latest/news/three-nordic-countriesincrease-mil-among-all-citizens

Hobbs, R. (2016). Exploring the roots of digital and media literacy through personal narrative. Philadelphia: Temple University Press.

Jaakkola, M. (2018a). En lång tradition av mediefostran [A long tradition of media nurturing]. In U. Carlsson (Ed.), Medie- och informationskunnighet (MIK) i den digitala tidsåldern: En demokratifraga [Media and information literacy in the digital age: A question of democracy] (pp. 187-198). Gothenburg: Nordicom, University of Gothenburg.

Jaakkola, M. (2018b, April 19). Report: Finland's media policy lacks a citizen's perspective. Retrieved April 7, 2020, from https://www.nordicom.gu.se/en/latest/news/report-finlands-media-policylacks-citizens-perspective.

Jaakkola, M. (2019, December 17). Finland's national policy for media education updated. Retrieved May 3, 2020, from https://www.nordicom.gu.se/en/latest/news/finlands-national-policy-mediaeducation-updated

Kellner, D., \& Share, J. (2019). The critical media literacy guide: Engaging media and transforming education. Leiden, Netherlands: Brill Sense.

Kotilainen, S., \& Arnolds-Granlund, S-B. (Eds.). (2010). Media literacy education: Nordic perspectives. Gothenburg: Nordicom, University of Gothenburg.

Kupiainen, R., Sintonen, S., \& Suoranta, J. (2008). Decades of Finnish media education. Finnish Society on Media Education: Tampere University Centre for Media Education. Retrieved No- 
vember 1, 2019, from https://www.researchgate.net/publication/257116839_Decedes_of_Finnish_Media_Education

Livingstone, S., van Couvering, E., \& Thumin, N. (2008). Converging traditions of research on media and information literacies: Disciplinary, critical and methodological issues. In J. Coiro, C. Knobel, D. Lankshear, \& D. J. Leu (Eds.), Handbook of research on new literacies (pp. 103-132). New York: Routledge. https://doi.org/10.4324/9781410618894

Masterman, L. (1985). Teaching the media. London: Comedia.

Mihailidis, P. (2014). Media literacy and the emerging citizen: Youth, engagement and participation in digital culture. New York: Peter Lang. https://doi.org/10.3726/978-1-4539-1293-5

Minkkinen, S. (1978). A general curricular model for mass media education. Madrid: UNESCO.

Potter, J. W. (2010). The state of media literacy: Education for tomorrow's media. Journal of Broadcasting \& Electronic Media London, 54(4), 675-696. https://doi.org/10.1080/08838151.2011 .521462

Rydin, I. (2003). (Ed.) Media fascinations: Perspectives on young people's meaning making. Northern Perspectives 4. Gothenburg: Nordicom, University of Gothenburg.

Staksrud, E. (2014). The Nordic media literacy model - Seemingly sober? In U. Carlsson (Ed.), Medieoch informationskunnighet $i$ Norden: En nyckel till demokrati och yttrandefribet [Media and information literacy in the Nordic countries: A key to democracy and freedom of speech] (pp. 151-158). Gothenburg: Nordicom, University of Gothenburg.

Stigbrand, K. (1989). Mediekunskap i skolan: En studie av massmedieundervisningens ABC [Media knowledge in school: A study of the ABCs of mass media teaching] [Doctoral dissertation, Stockholm University, Sweden].

Syvertsen, T., Enli, G., Mjøs, O. J., \& Moe, H. (2014). The media welfare state: Nordic media in the digital era. Ann Arbor, Michigan: The University of Michigan Press.

Tufte, B. (1995). Skole og medier: Byggesat til de levende billeders padagogik [School and media: A kit for the pedagogics of living images] [Dissertation, Danmarks Lærerhøjskole, Copenhagen, Denmark].

Valtioneuvosto Statsrådet. (2013). Good Media Literacy; National Policy Guidelines 2013-2016. Retrieved April 7, 2020, from https://julkaisut.valtioneuvosto.fi/handle/10024/75280

von Feilitzen, C., \& Carlsson, U. (Eds.). (1999). Children and media: Image education participation. Yearbook 1999. Gothenburg: Nordicom, University of Gothenburg/The UNESCO International Clearinghouse on Children and Violence on the Screen.

von Feilitzen, C. (Ed.). (2004). Young people, soap operas and reality TV. Yearbook 2004. Gothenburg: Nordicom, University of Gothenburg/The UNESCO International Clearinghouse on Children, Youth and Media.

Wadbring, I., \& Pekkala, L. (Eds.). (2017). Citizens in a mediated world: A Nordic-Baltic perspective on media and information literacy. Gothenburg: Nordicom, University of Gothenburg.

Wan, A. (2014). Producing good citizens: Literacy training in anxious times. Pittsburgh: Pittsburgh Press.

Copyright: (C) 2020 The Author(s) and Nordicom. This is an Open Access article distributed under the terms of the Creative Commons Attribution 4.0 International License (CC BY-NC-ND 4.0). 